\title{
Parched prospects \\ The emerging water crisis in South Africa
}

\author{
Steve Hedden and Jakkie Cilliers
}

\begin{abstract}
Summary
South Africa is over-exploiting its freshwater resources and water could be a large constraint on the implementation of the National Development Plan. Using the International Futures forecasting system, this paper models and forecasts water demand and supply until 2035, the period covered by the National Water Resource Strategy 2013. The authors' research finds that the gap between demand and supply increases and that the solutions proposed by the Department of Water Affairs and Sanitation will not close the gap without additional, aggressive measures. The authors propose such measures for each sector of demand and each source of water supply.
\end{abstract}

\section{WATER CRISES ARE emerging}

worldwide at all levels - from local farmerherder conflicts in north-eastern Kenya to concerns about city-level sustainability (as is the case with the capital of Yemen, Sana'a). These crises occur nationally and even across entire regions. Water scarcity now ranks as the third most concerning global risk, according to the World Economic Forum, ${ }^{1}$ although the nature of potential water crises differs from one country to another as well as within individual countries.

South Africa is a water-scarce country. The National Development Plan 2030 clearly states that food, fuel and water are interconnected, particularly in the context of climate change and their impact on one another. ${ }^{2}$ During a media briefing, the former minister of Water and Environmental Affairs, Edna Molewa, was succinct in her summary: 'The situation currently in South Africa is that we have $98 \%$ of the water in the country being considered "fully allocated". This means that my child and your child that is being born tomorrow has $2 \%$ of water for use going into the future.'

Of the 223 river ecosystem types in South Africa, 60\% are threatened and $25 \%$ of those are critically endangered. The situation with the 792 wetland ecosystems is even worse. ${ }^{4}$

This paper presents a forecast of South Africa's water demand for the next two decades, using the International Futures (IFs) global forecasting system to develop the associated forecasts to 2030 (the time frame for the National Development Plan) and 2035 (the time frame for the national water strategy). Where data sources are not explicit in this paper, figures have been taken from IFs. Additional information on IFs as well as the interventions used for this paper are included in a separate annexure.

This paper bases its forecast on the water supply-and-demand information available in various documents, such as the National Water Resource Strategy 2013 (NWRS2), and concludes with the observation that water scarcity may shortly emerge as one of the most significant constraints on South Africa's human-development prospects.

Water scarcity is not the only potential water-related challenge. Too much water 


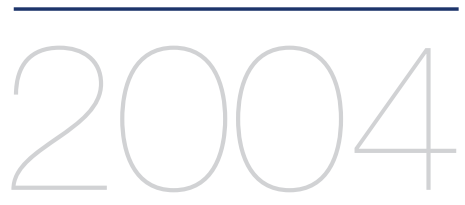

THE FIRST NATIONAL WATER RESOURCE STRATEGY RELEASED AS A BLUEPRINT FOR WATER-RESOURCE MANAGEMENT

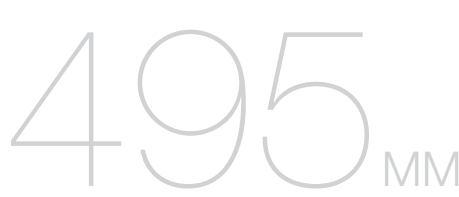

AVERAGE ANNUAL RAINFALL IN SOUTH AFRICA, WHEREAS THE WORLD AVERAGE IS

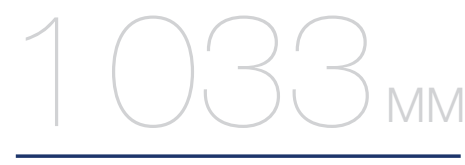

can result in floods - like the 2010 floods in Pakistan that submerged a fifth of the country and killed close to 2000 people. ${ }^{5}$ Also, water quality can be as serious a problem as water quantity. ${ }^{6}$ Acid mine drainage, often associated with heavy metals like uranium, ${ }^{7}$ is a major risk in the Witwatersrand goldfields ${ }^{8}$ and Mpumalanga coalfields. ${ }^{9}$ That said, this paper does not explicitly model the problem of floods, water pollution or water quality in South Africa but mainly limits itself to national levels of water supply and demand. Nor does it concern itself with the inequities in the allocation of and access to water (the result of apartheid) other than a brief mention of the challenge that water licensing presents in terms of controlling and providing for greater equity in future water usage. ${ }^{10}$

For the purposes of this paper, water scarcity can simply be defined as a higher level of total water demand than available supply. ${ }^{11}$ Water scarcity is different from water shortage or water stress. Water shortages can occur
South Africa is characterised by low and variable annual rainfall along with high natural evaporation levels, making it the 30th driest country in the world. ${ }^{13}$ Average annual rainfall in South Africa is only $495 \mathrm{~mm} ;{ }^{14}$ whereas the world average is $1033 \mathrm{~mm} .{ }^{15}$ Evaporation losses are often three times more than rainfall. Furthermore, the meagre rainfall is unevenly distributed, with some regions receiving less than $100 \mathrm{~mm}$ of rain in a year on average. ${ }^{16}$ The National Development Plan notes that 'since South Africa is already a water-scarce country, greater attention will have to be paid to [the] management and use [of water]'. ${ }^{17}$ Water resources and the environment are particularly under threat in the Mpumalanga Highveld coalfields, upstream of the Vaal and Loskop dams and in the Lephalale-Waterberg area, arising from the mining and combustion of coal. The National Development Plan also calls for the urgent need to revise water allocations in the upper Vaal and Olifants River water-management areas. ${ }^{18}$ Not only is South Africa a dry country (with less water per capita than, for

\section{Low and unpredictable supply, coupled with high demand and poor use of existing resources, make South Africa a water-constrained country}

because of a lack of available supply, but also as a result of faults in infrastructure, environmental changes or deteriorating water quality. Water stresses are the symptoms of water scarcity or water shortages. These symptoms could be conflict or competition over scarce water resources, declining standards of reliability and service, harvest failures or food insecurity. ${ }^{12}$ Low and unpredictable supply, coupled with high (and growing) demand and poor use of existing water resources, make South Africa a waterconstrained country. example, Namibia and Botswana, which are considered arid), but it also uses more water on a per capita basis than most others. World average water consumption is 173 litres per person per day; the average per capita water consumption in South Africa is 235 litres. ${ }^{19}$ In his 2010 state-of-the-nation address, President Jacob Zuma said, 'We are not a water-rich country. Yet we still lose a lot of water through leaking pipes and inadequate infrastructure. We will be putting in place measures to reduce our water loss by half by 2014. ${ }^{20}$ 
However, little immediate progress has been made to fulfil that commitment: a 2012 study conducted by the Water Research Commission found that 36,8\% of municipal water is lost through physical leakages or commercial losses. ${ }^{21}$ This despite the fact that in 2011 the South African Local Government Association and the Water Research Commission re-established the benchmarking of water services in South Africa through the launch of the national Municipal Benchmarking Initiative for Water Services, which was aimed at improving efficiencies in water management. ${ }^{22}$

\section{Over-exploitation and assured yield}

To understand what is meant by the term 'over-exploitation', it is important to know how 'exploitable water resource', or 'reliable yield', is defined.

The yield from a water resource is the volume that can be extracted at a certain rate over a specified period of time. This yield is usually measured in cubic kilometres per year. Since the volume of water in water systems varies throughout the year, the amount of water that can be extracted on a reliable basis ('reliable yield') is the amount that can be extracted at the period of lowest flow. By holding water in dams during periods of high flow and releasing that water during periods of low flow, the volume of water that can be extracted on a regular basis (i.e. the yield) is increased.

Because the level of water in a water system (the flow) varies from year to year and from season to season, the yield also changes from year to year. Yield is calculated in terms of assurance of supply. The amount of water that can be extracted on a regular basis for 98 out of 100 years is then referred to as the yield at a $98 \%$ assurance of supply. Using this formulation, the NWRS2 estimates that only $10,24 \mathrm{~km}^{3}$ out of South Africa's total mean annual run-off of $49 \mathrm{~km}^{3}$ is available as assured yield. ${ }^{23}$

Therefore, over-exploitation does not necessarily create a scarcity of water. If the flow of a water system is above average for a given year, then withdrawing more water than the yield may not be a problem. If, however, a drought occurs, over-exploitation increases vulnerability to water shortages. For this reason, agriculture is given a lower assurance of supply (30\%) and this is embedded in dam operating rules, so that in times of drought, the supply of agriculture water gets cut in preference to industrial and urban water supply.

\section{National Development Plan 2030 and National Water Resource Strategy 2013}

The first National Water Resource Strategy (NWRS1) was released in 2004 as a blueprint for water-resource management and as one of the requirements of the 1998 National Water Act. ${ }^{24}$ The NWRS1 provided quantitative information about the present and future availability of and requirements for water in each of the then 19 watermanagement areas ${ }^{25}$ until 2025. ${ }^{26}$

The NWRS 2013 is the second edition of the report (hence NWRS2). It seeks to 'ensure that national water resources are managed towards achieving South Africa's growth, development and socioeconomic priorities in an equitable and sustainable manner over the next five to 10 years. ${ }^{27}$ The report is a response to the 2011 National Development Plan and outlines the strategy to meet the relevant goals set in the National Development Plan by providing targets through to 2035. Recognising the need to improve water-resource planning and management, the National Water Resource Strategy will now be reviewed every five years. ${ }^{28}$ The NWRS2 provides hard targets for increasing water supply for each of the recently promulgated nine water-management areas.

Among its many goals, the National Development Plan set the following interrelated targets: all South Africans should have access to clean running water in their homes by 2030 (the current proportion is estimated at $92 \%$ by IFs);29 South Africa should achieve a food trade surplus; and the country should produce sufficient energy. The National Development Plan proposes a $33 \%$ increase in the area of land currently under irrigation 'through the better use of existing water resources and [by] developing new water schemes'.$^{30}$ It states that efforts should be made to make mineral extraction less waterintensive, advocates investments in infrastructure for water, and proposes achieving an average reduction in water demand of $15 \%$ below baseline levels in urban areas by $2030 .{ }^{31}$

\section{Current water demand and supply in South Africa}

The NWRS2 does not provide explicit data on the current water demand by sector and is somewhat reliant on the studies carried out for the 2004 report. That report put total water withdrawal at $12,87 \mathrm{~km}^{3}$ and exploitable yield at $13,23 \mathrm{~km}^{3}$. While this implies a surplus of water still existed in South Africa in 2004 , more than half of the water-management areas were already being over-exploited. More recent studies ${ }^{32}$ have shown that the NWRS1 may have overestimated water supply. Demand has increased since 2004 and rather than the small positive balance reported in 2004, South Africa is currently over-exploiting its renewable water resources on a national level.

Using the most recent data available for water demand in each sector, as well as the driving variables for water demand, the authors estimate that South Africa is currently withdrawing $15,6 \mathrm{~km}^{3}$ of water 
per annum. The agricultural sector is the largest user of water, accounting for $57 \%$ $\left(8,9 \mathrm{~km}^{3}\right)$ of total water usage. Municipal demand accounts for $35 \%\left(5,5 \mathrm{~km}^{3}\right)$ of water usage and the industrial sector accounts for the remaining $8 \%\left(1,2 \mathrm{~km}^{3}\right)$ (see Figure 1).

\section{Figure 1: Current South African water demand by sector}

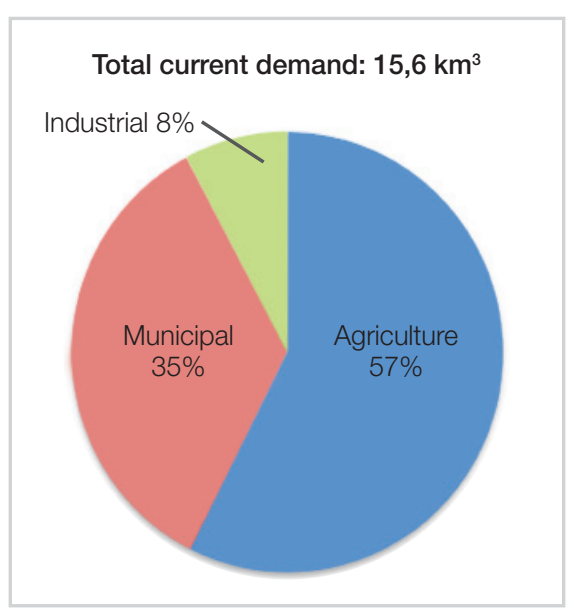

Source: IFs version 7.0. Historical data from NWRS2 (ch.2 p. 29).

As discussed, the NWRS2 estimates that the exploitable surface-water yield available on a $98 \%$ assurance of supply is $10,24 \mathrm{~km}^{3}$. Even if one includes the $2,1 \mathrm{~km}^{3}$ of treated wastewater produced each year, surface water is being heavily over-exploited at the national level. South Africa's capacity to build more dams is limited by the availability of streamflow, and under conditions of climate change this is likely to decrease as evaporative losses of open water increase. ${ }^{33}$ More than two-thirds of South Africa's mean annual run-off is already stored in dams, limiting streamflow to a bare minimum. ${ }^{34}$ In the case of the Orange River, for every 100 units of rain that fall across the entire basin, only 5,1 units end up in the river (as opposed to in dams). If one calls these 5,1 units 100 per cent of run-off, then South Africa has dams capable of storing almost double this flow. ${ }^{35}$
The NWRS2 estimates that current groundwater withdrawal in South Africa is at $2 \mathrm{~km}^{3}$ out of exploitable groundwater resources estimated at $5,5 \mathrm{~km}^{3}$. Allowing for an underestimation of exploitable groundwater resources, the NWRS2 estimates a total potential of about $3,5 \mathrm{~km}^{3}$ of groundwater available for exploitation. ${ }^{36}$

\section{Figure 2: Current South African water supply}

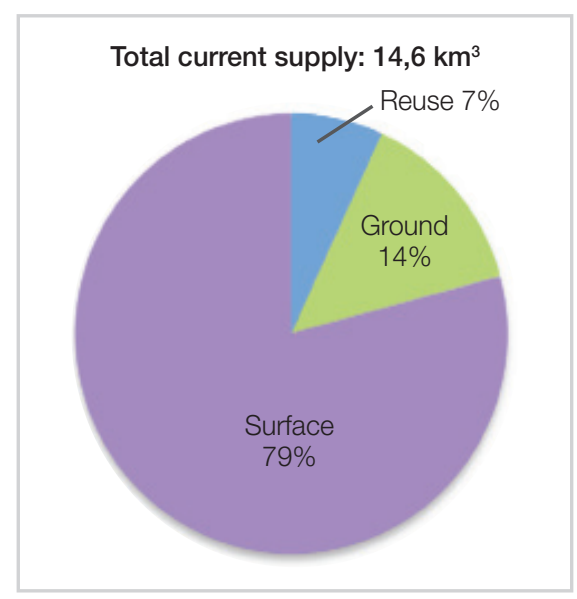

Source: IFs version 7.0. Historical data taken from NWRS 2004 and the FAO's Aquastat database.

South Africa has over 1000 watertreatment facilities currently in operation discharging $2,1 \mathrm{~km}^{3}$ of treated water back into the river systems - although the quality of the treated water is often suspect. ${ }^{37}$ Direct reuse of this water is minimal but since the treated water is discharged into the river systems it is available as a secondary water source. For the purposes of this forecast, this treated wastewater is included in the exploitable surface-water category.

Desalination is being implemented on a small scale in South Africa. The industrial and mining sectors desalinate used water for reuse. Brackish groundwater desalination by reverse osmosis provides drinking water to small towns and communities along the west coast. Desalination of acid mine drainage has been pioneered 
in eMalahleni and is now under consideration for the Witwatersrand goldfields. Seawater desalination is being used to supplement municipal water supplies in towns along the southern and Eastern Cape coastlines. In 2000, however, this accounted for just 0,018 $\mathrm{km}^{3}$ of the country's freshwater supply. ${ }^{38}$ The authors estimate that South Africa currently desalinates about $0,025 \mathrm{~km}^{3}$ of water.

\section{Modelling water supply and demand}

To forecast South Africa's water sector, this paper uses the International Futures forecasting model (IFs). For a more detailed description of the model, and specifically the water sub-module, please refer to the annexure.

To model water supply, the authors use the sum of assured surface water yield, renewable groundwater withdrawal non-renewable (fossil) groundwater withdrawal, treated and reused wastewater, and desalinated water. Treated wastewater that is not directly reused is added to surfacewater yield.

This paper forecasts water demand using separate equations for the three main sectors of water usage: municipal, industrial and agricultural. The main driver of municipal water demand is the size of a country's urban population (around 33,2 million for South Africa. The main driver of industrial water demand is power generation ${ }^{39}$ ( $2 \%$ of total South African water usage $\left.{ }^{40}\right)$. The main driver of agricultural water demand comes from the 1,6 million hectares of land equipped for irrigation. ${ }^{41}$

\section{Forecasting water demand}

Demand for water in South Africa can be reasonably expected to increase in all sectors. A growing manufacturing sector and an increase in the number of thermoelectric power plants will increase industrial-sector water demand. The National Development Plan and the Integrated Resource Plan for Electricity anticipate a need to build an extra $40 \mathrm{GW}$ of electricity generating capacity by 2030 , most of which will be thermoelectrically generated. ${ }^{42}$ The onset of renewable energy in the early 2030s, however, will cause industrial water demand to decrease. Rural-urban migration and rising income levels will increase the residential consumption of water. Although the agriculture sector contributes only $3 \%$ of GDP and accounts for just $7 \%$ of formal employment, about 8,5 million people are dependent on agriculture for employment and income. Irrigated agriculture is the largest single consumer of water in South Africa, with around 1,6 million hectares equipped for irrigation. ${ }^{43}$ While the Department of Water Affairs and Sanitation assumes there will be no increase in the amount of water allocated for irrigation purposes, the National Development Plan, on the other hand, makes provision for increasing the area of land under irrigation by 33\% by 2030 as an important component of its jobcreation efforts. ${ }^{44}$ The target in the NWRS2 is even higher - with an anticipated increase of $50 \%$ of the land under irrigation. ${ }^{45}$

The National Development Plan highlights agriculture as a key driver of food security, job creation and social capital of rural communities, and it is difficult to see how the area of land under irrigation could be increased without increasing agricultural water demand. ${ }^{46}$ Thus, water demand will increase in all sectors, including agriculture.

The authors' base case forecast of water usage (see Figure 3) is that the largest increase in water demand by 2035 will come from the municipal sector, followed by industrial (which includes energy and mining), and agriculture.
Municipal water demand is forecast to increase from $5,5 \mathrm{~km}^{3}$ in 2014 to $7,2 \mathrm{~km}^{3}$ by 2035 . Industrial water demand increases from $1,2 \mathrm{~km}^{3}$ to over $3 \mathrm{~km}^{3}$ in 2030 and then decreases to $2,8 \mathrm{~km}^{3}$ by 2035. This decline is due to the onset of renewable-energy production, which does not require water for cooling. Agricultural water demand increases from $8,9 \mathrm{~km}^{3}$ to $9,7 \mathrm{~km}^{3}$. The rise in municipal water demand is due to increasing rural-urban migration, specifically to the provinces of Gauteng and the Western Cape, ${ }^{47}$ and rising income levels. Industrial demand will increase as a result of rising electricity demand - also a result of urban migration and economic growth.

Even though the NWRS2 does not anticipate an increase in agricultural water demand, government's intention to increase the area of land under irrigation will increase water demand for the agricultural sector unless sufficient advances are made in water efficiency or water-withdrawal licences are transferred to other sectors.

\section{Figure 3: Base case forecast of South African water demand by sector}

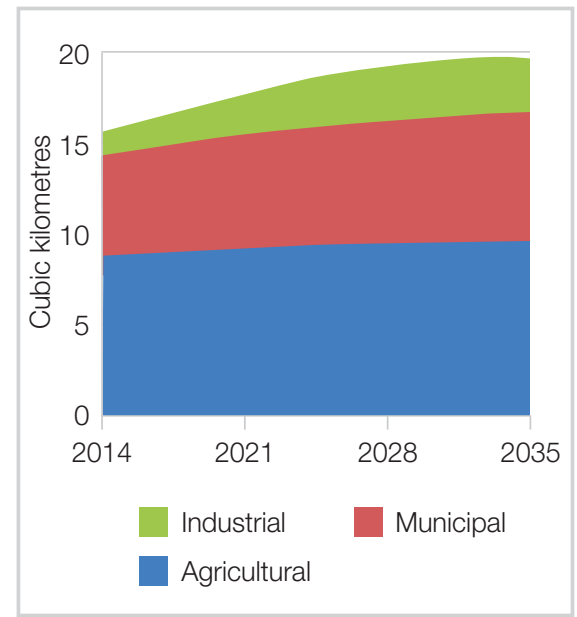

Source: International Futures (IFs) version 7.0.

\section{Other demand forecasts}

Two other forecasts of water demand have produced roughly similar findings, 
both of which provide independent corroboration of the present authors' forecasts.

\section{A 2009 report by the Water Resource Group $2030^{48}$ includes a case study on the growing demand-supply gap in South Africa's water sector. This report forecasts that by 2030, water demand in South Africa would be $17,7 \mathrm{~km}^{3}$. Given the cap on agricultural water withdrawals, it forecasts no change in agricultural water yield by about $1 \mathrm{~km}^{3}$ by 2035 . Much of this will come from Phase 2 of the Lesotho Highlands Water Project, which supplies water to Gauteng through transfer from the Katse and Mohale dams in Lesotho to the Upper Vaal Management Area, to be completed in $2020 .{ }^{52}$} water demand - the report puts this figure unchanged at $8,4 \mathrm{~km}^{3}$. The Water Resource Group forecasts an increase to $6 \mathrm{~km}^{3}$ in municipal water demand and $3,3 \mathrm{~km}^{3}$ in industrial water demand. Its forecast leads to a demand-supply gap of 17 per cent by 2030.49

The Department of Water Affairs and Sanitation published a report in May 2013, A strategic overview of the water sector of South Africa 2013. While this report does not give explicit demand forecasts for each sector, it does state that current usage is estimated to be between 15 and $16 \mathrm{~km}^{3} /$ annum, which correlates well with the present authors' estimate of $15,6 \mathrm{~km}^{3}$. According to the report, without effective metering and billing, consumption in urban and rural areas could rise to over $7,3 \mathrm{~km}^{3} / \mathrm{annum}$, resulting in an increase in total water usage of close on $20 \mathrm{~km}^{3} /$ annum. ${ }^{50}$

\section{Future water supply in South Africa}

This section reviews water supply from surface water, groundwater, water reuse and desalination (see Figure 4).

To increase water supply, the NWRS2 plans for increased investment in surface water infrastructure, mainly from dams - although all significant rivers are at maximum yield, with few remaining dam sites and little remaining streamflow. The areas where additional water is still available, such as in the uThukela, Mzimvubu and Pongola basins, are a long way from existing centres of demand. ${ }^{51}$

The strategy plans to increase surface-

\section{Figure 4: Base case forecast of South African water supply}

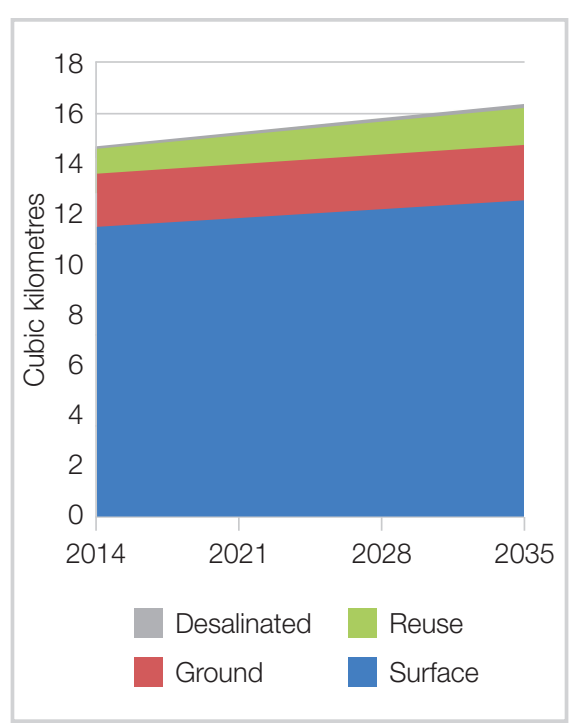

Source: International Futures version 7.0

With respect to groundwater, the NWRS2 plans to increase usage by $0,117 \mathrm{~km}^{3}$ by 2035 . Although more water can be reliably extracted from underground aquifers, it is unlikely that South Africa will be able to increase groundwater withdrawals to the $3,5 \mathrm{~km}^{3}$ limit by 2035 .

The NWRS2 sets hard targets for the reuse of water for several watermanagement areas. Altogether, the strategy proposes the reuse of over a quarter of a cubic kilometre of wastewater by $2035 .{ }^{53}$

Finally, the NWRS2 lays out plans to increase the use of desalinated water in several water-management areas. The plan calls for at least $0,15 \mathrm{~km}^{3} /$ annum by 2035 in at least three water-management areas. The eThekwini municipality, which includes Durban, is, for example, currently looking into the possibility of building a large-scale desalination plant to offset rising demand. ${ }^{54}$

One way to reduce water demand is to decrease the volume of water that is lost through physical leakage or commercial losses, referred to as non-revenue water. ${ }^{55}$ A 2012 study by the Water Research Commission collected data on 132 of the 237 municipalities in South Africa, which represents $75 \%$ of the total volume of municipal water supply. ${ }^{56}$ The study found that $36,8 \%$ of municipal water withdrawal was non-revenue water - most of which was a result of direct physical losses. This is on par with the global average of $37 \%$ but much higher than other water-scarce countries like Australia, whose non-revenue water is less than $10 \%$ of municipal demand. ${ }^{57}$ The report estimates that in 2010 national non-revenue water was 1,6 km³ - or about a third of total municipal water supplied. ${ }^{58}$

According to the NWRS2, non-revenue water losses in the irrigation sector are between $35 \%$ and $45 \% .^{59}$

The National Development Plan states that an average reduction in water demand of $15 \%$ below baseline levels is possible to achieve in urban areas by $2030 .{ }^{60}$ It must be noted, however, that water 'lost' in this way actually contributes to groundwater recharge, although this value has never been quantified in any robust way.

\section{Forecasting the demand- supply gap}

To model the NWRS2's ability to close the gap between demand and supply, the authors built a supply forecast that simulates the NWRS2 plans to increase supply utilising the IFs model. 
This includes all of the explicit supply increases outlined in the strategy. As seen in Figure 5, increasing supply, as proposed in the NWRS2, will not be sufficient to meet the growing demand for water.

The gap between demand and supply increases to over $3,5 \mathrm{~km}^{3}$ by 2030 , and is only reduced to $3,2 \mathrm{~km}^{3}$ by 2035 . This reduction in the gap, which is predicted to take effect from 2030, is largely because of the expected drop in coal production together with continued growth in renewable energy.

Figure 5: South Africa's increasing gap between water demand and supply

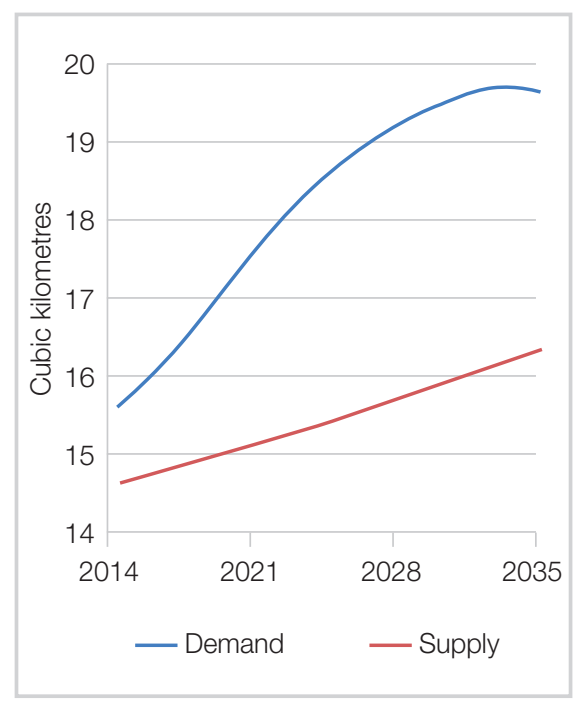

Source: IFs version 7.0

\section{Water as a constraint on growth}

If demand for water continues to exceed supply, then water resources in South Africa will be continuously over-exploited. This has serious consequences on the environmental resilience of aquatic ecosystems and the reliability of water supply for human consumption. Overexploitation of water will also constrain growth, employment and general human development, since hydrology is a defining variable of the potential performance of water-constrained countries' economies.

On 16 January 2004, the president of South Africa declared six provinces disaster zones and 4 million South Africans were at risk of food shortages due to drought. ${ }^{61}$ The government allocated R500 million to drought-relief services in the form of emergency relief for vulnerable communities, fodder and water for livestock, water for human consumption, safeguarding of boreholes and prevention of communicable diseases in poor rural areas that were affected. ${ }^{62}$ In 2013 the North West province was declared drought-stricken by the Disaster Management Act. ${ }^{63}$ This led to drought-response action in the form of fodder supplies as well as imported drinking water, as the Mamusa Dam almost dried up. ${ }^{64}$

Over-exploitation of freshwater resources increases the chances that a drought, like the one that occurred in 2004, will exacerbate water shortages. If there is not a reliable supply of water, whatever the source, then communities and industries that rely on rainfall will experience water shortages.

To illustrate the extent of water as a constraint on growth, we turn to the 'Mandela magic' ('high road') scenario from the South African futures 2030 paper. ${ }^{65}$ In this scenario, South Africa grows at an average rate of 5,1\% from 2014 to 2030 (compared to an average growth rate of 3,8\% forecast for an amended baseline called 'Bafana Bafana' in the same paper) and has, by 2030 , an economy that is $23 \%$ larger than the base-case forecast.

Economic development increasingly drives water demand. Most of this increased demand comes from the industrial sector - total water requirements are 0,7 km higher in 2035 in the 'Mandela Magic' scenario than in the base case, depicted in Figure 6.

\section{Figure 6: Growing gap between water demand and supply in the Mandela Magic scenario}

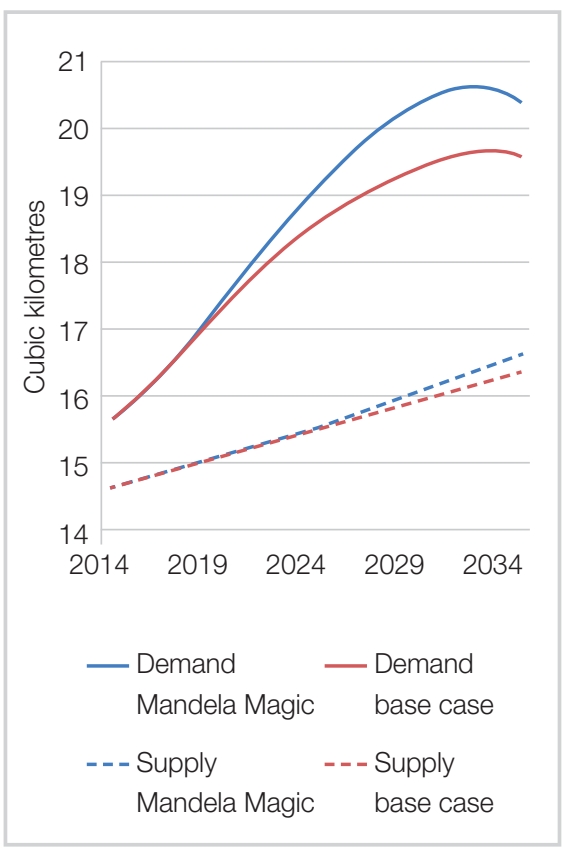

Source: IFs version 7.0

Economic growth is also expected to drive investment in wastewater treatment facilities, thereby increasing overall water supply. Although more wastewater is treated in this 'high road' scenario, more untreated wastewater is also produced, resulting in more contamination of water catchments. Furthermore, the increase in supply is outweighed by the increase in overall demand, resulting in an even larger gap between demand and supply than in the base case. The gap increases from $3,23 \mathrm{~km}^{3}$ in the base case in 2035 to $3,77 \mathrm{~km}^{3}$ in the 'Mandela Magic' scenario.

Water is therefore a significant constraint on South Africa's development potential and the next section looks at how this gap can be closed.

\section{Closing the gap}

This section discusses methods of reducing water demand and increasing supply and includes a summary of 
the associated scenario called 'close the gap'.

\section{Reducing demand}

The average per capita water consumption in South Africa is higher than in most other countries, so behavioural changes in municipal consumption are particularly important. Central to this required change in attitude is the emerging global notion of stewardship, which is based on an ethos of sustainable custodianship rather than on consumption. South Africans currently use $27 \%$ more municipal water than we would expect given the size of the urban population. The NWRS2 sets the goal to 'reduce water demand in urban areas to $15 \%$ below business-as-usual scenario by 2030 ' ${ }^{66}$ To achieve this, the strategy proposes water-conservation and water-demand-management programmes. This target, however, is not aggressive enough.

Reducing the volume of non-revenue water will greatly curtail the rise in municipal water demand. Better monitoring of municipal and industrial water supply might also help reduce lost water. New technology, such as advanced metering infrastructure, could also help to reduce these losses. ${ }^{67}$ If per capita municipal consumption were lowered to the world average by 2035 (a significant challenge in itself), the demand-supply gap would be reduced by almost half. ${ }^{68}$ In the 'close the gap' scenario, municipal water demand falls from $7,18 \mathrm{~km}^{3}$ in 2035 in the base case to $5,74 \mathrm{~km}^{3}$. This is some $20 \%$ lower than in the base case - though still above the expected value given the size of South Africa's urban population when compared to urban water use globally.

While the National Development Plan acknowledges that investment in agricultural irrigation may have many social and economic benefits, and aims to increase the area of land under cultivation, the NWRS2 does not allow for any increase in water allocation for the agricultural sector.

The authors' analysis shows that South Africa uses less water for agriculture than one would expect given the area of land equipped for irrigation. ${ }^{69}$ This does not necessarily mean, however, that water is being used efficiently in irrigation schemes. A study by the Bureau for Food and Agricultural Policy (BAFP)
Even with all these improvements in efficiency, water demand still increases in each sector over the time horizon implying that the reduction in demand levels is insufficient. Supply also has to increase, as discussed in the next section.

Finally, South Africa faces a legacy of a skewed allocation of water rights. As a first step towards a more equitable system, the minister of Water and

\section{Almost without exception, municipal wastewater is not being utilised in South Africa}

indicates that allocated water is being stretched over larger areas, exposing farmers to risk of crop failure. ${ }^{70}$ The use of open canals, many of which are in a dilapidated state, make these reticulation systems extremely inefficient. Therefore, the apparent under-use of water in agriculture represents a risk rather than an achievement in efficiency.

The economic benefits of irrigation should not be understated. While the NWRS2 claims that agriculture contributes only $3 \%$ to the national economy, it is estimated to contribute as much as $18 \%$ in secondary processing. ${ }^{71}$ In the 'close the gap' scenario, the demand for agricultural-use water decreases by only $2 \%$ compared to the base case by 2035. This assumes gains in water-use efficiency as well as increases in the area of land equipped for irrigation.

Thermoelectric power generation, the manufacturing sector and the mining sector will primarily drive industrial water demand. Although these are economically important industries, their water needs must be balanced with the needs of other sectors. Industrial water demand decreases by $10 \%$ compared to the base case.
Environmental Affairs embarked upon the National Water Policy Review in August 2013. This review included an effort to ban all trading between authorised water users, a move towards a 'use it or lose it' principle, and prioritised social and economic equity in the reallocation of water. $^{72}$ Efforts to rebalance water rights will be constrained by the supply-anddemand challenges outlined in this paper.

\section{Increasing supply}

In addition to the $1,87 \mathrm{~km}^{3}$ reduction in overall water demand in 2035, the IFs model forecasts an increase in exploitable water supply by $1,43 \mathrm{~km}^{3}$ in comparison to the base case. Bear in mind that the base case already includes the hard targets set out in the NWRS and these supply increases are in addition to the plans of the NWRS. Surface water is over-exploited on a national level and while infrastructure is being built to increase the reliable yield, there is a limit on the ability of dams and redistribution networks to satisfy growing demand. South Africa is rapidly approaching this limit and, in the case of the Orange River, has already passed the limit. ${ }^{73}$

Almost without exception, municipal wastewater is not being utilised in South Africa - another opportunity to increase water supply. In addition, reducing non- 
revenue water represents an opportunity to decrease municipal water demand.

Groundwater offers another potential way of meeting some of the supply increases. Groundwater is currently not over-exploited on a national level and there is room to increase groundwater extraction significantly, especially in rural areas and on small farms. The forecast increases exploitable groundwater from $2,19 \mathrm{~km}^{3}$ in 2035 in the base case to $2,93 \mathrm{~km}^{3}$ in the 'close the gap' scenario. It is important to point out, however, that data on groundwater extraction is difficult to obtain and that the volume of groundwater that can be reliably extracted is even harder to estimate. Furthermore, groundwater scarcity is a localised constraint and while supply may currently exceed demand on the national level, many aquifers in South Africa are already being over-exploited.

There is some room for developing surface water, but the base case already includes planned infrastructure development, like Phase 2 of the Lesotho Highlands Water Project. Exploitable surface water yield can be increased, however, through the treatment of wastewater. In the 'close the gap' scenario, $80 \%$ of municipal wastewater is treated. Two-thirds of this is then directly reused and the remainder is available as exploitable surface water. Collectively, this contributes more than half a cubic kilometre to overall water supply. An important consideration here is the high levels of evaporation loss. For example, of the rainfall over the Orange River, up to $95 \%$ is lost to evaporation and transpiration combined. ${ }^{74}$ Looking ahead, evaporation loss can probably only be contained by resorting to the storage of water in underground aquifers.

In the 'close the gap' scenario, desalination is increased by $70 \%$ against the base case, yet it still contributes very little to overall water supply on a national level. Starting from such a small base, it is difficult for desalination to play a significant role in the South African water sector for the next 20 years. ${ }^{75}$ Desalination plants are also energyintensive, so the gains in water supply must be balanced with the associated energy costs, which also require large amounts of water. Desalination also has a brine-disposal implication, which is easier to manage at the coast, but a significant constraint inland, such as with the planned desalination of acid mine drainage from the goldfields.

An option that this paper did not consider is for South Africa to import more water than it already does from Lesotho. South Africa is a signatory to the Revised Protocol on Shared Water Courses in the Southern African Development Community (SADC) region, and shares four major river systems with six neighbours: the Orange, Limpopo, Inkomati and Usutu/Pongola. The SADC Regional Water Policy and the SADC Regional Water Strategy help provide a framework for collaboration in the region. The costs associated with such efforts are huge. For example, at its launch in 2010, Phase 2 of the Lesotho Highlands Water Project was estimated to cost approximately $\$ 1$ billion by $2020 .{ }^{76}$

\section{Summary results}

The policies set out in the NWRS2 are clearly not enough to address the water constraints facing South Africa. Even if policies that would close the demand-supply gap by 2035 are put in place now, South Africa will still be over-exploiting water for the next 20 years - even on South Africa's current growth path, which is significantly lower than that presented in the 'Mandela Magic' scenario. This over-exploitation increases the vulnerability of the water system to shocks like drought and will be aggravated by the impact of climate change. Clearly, any attempt to reconcile this gap must include policies to reduce demand, increase supply, improve efficiency and create the necessary incentives for the transition to a recycling economy, in which water of different quality and price is used for different purposes. $^{77}$

Achieving the 'close the gap' scenario requires significant investment in water supply - more than is explicitly called for in the NWRS2 - as well as much more efficient uses of water to reduce demand, as explained below. The results are presented in Figure 7.

\section{Figure 7: Base case supply and demand compared with}

'closing the gap' scenario

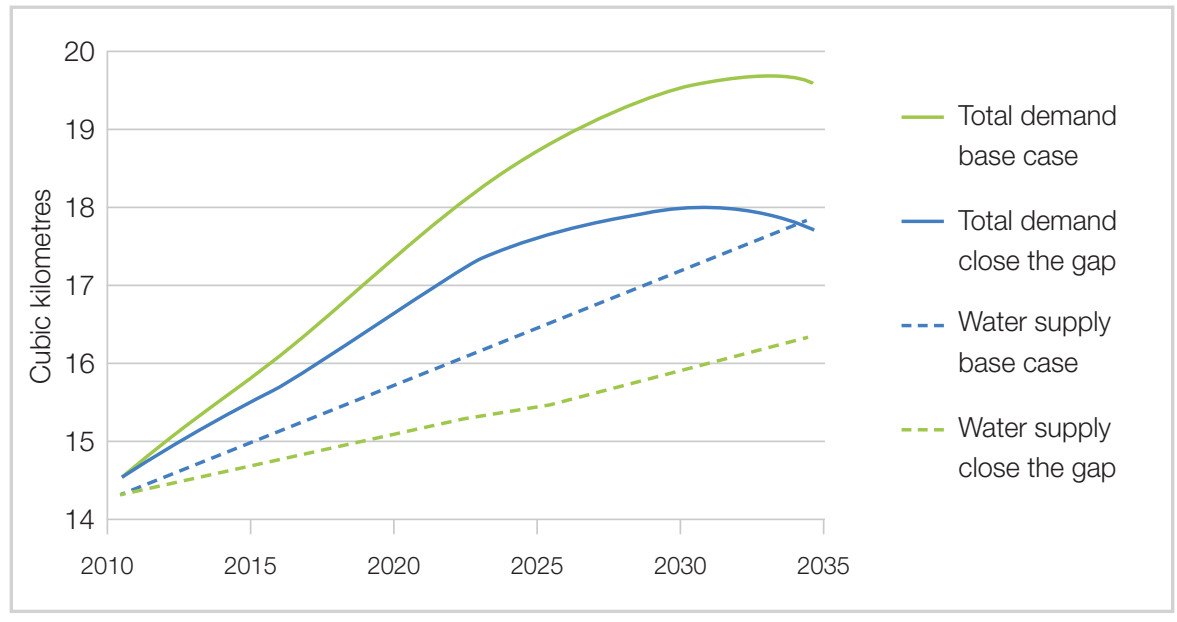

Source: IFs version 7.0 


\section{Figure 8: Decreases in water demand in 2035 in the 'closing the gap' scenario}

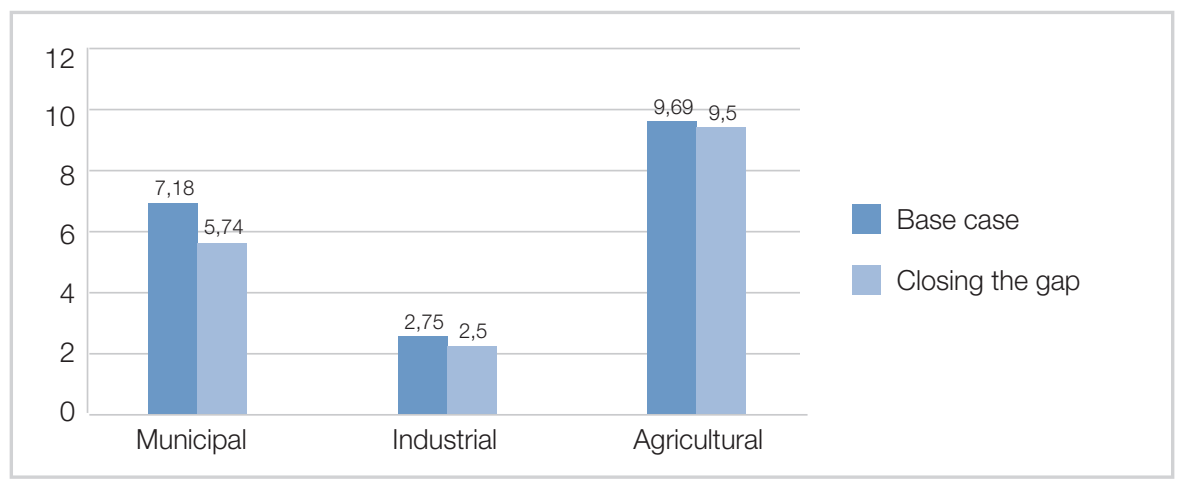

Source: IFs version 7.0

\section{Figure 9: Increases in water supply in 2035 in the 'closing the gap'} scenario

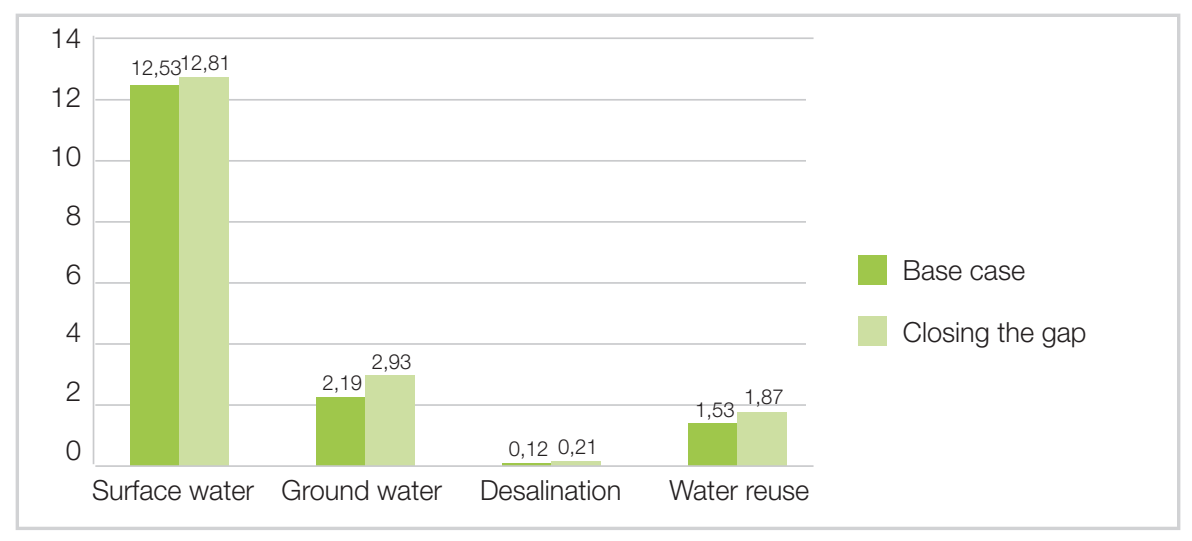

Source: IFs version 7.0

The base case forecasts a gap between supply and demand of $3,23 \mathrm{~km}^{3}$ in 2035. To close this gap, we set aggressive targets for each sector of demand and each source of water supply. Most of the gains come from demand management - primarily in the municipal sector. This would necessitate significant behavioural changes in urban water consumption, as well as reductions that come about from improvements in the management of nonrevenue water. Generally, the forecasts show that the overall increase in both land under irrigation and thermoelectric generation counteract improvements in efficiency, which means that water demand increases in every sector even with improvements in efficiency.
Figure 8 and 9 respectively present increases in water supply from each source and reductions in water demand from each usage sector that are needed to close the gap between demand and supply. This reflects the huge contribution made from greater efficiencies in the use of municipal water and exploitation of groundwater.

\section{Uncertainties}

The demand-supply forecast presented in this paper is not the only possible water-demand scenario for South Africa. There are many uncertainties that will affect both the supply and demand of water resources. In the base case scenario, it is assumed that the levels of exploitable surface and groundwater remain constant, and are only increased by means of investment in infrastructure (for surface water) or increased extraction (for groundwater). Climate change, however, could have a negative impact on the availability of both surface and groundwater, and diminish reliable yield over time. Hence, the NWRS2 states that 'climate change is expected to have a major impact on South Africa, with resulting consequences for people, the economy and ecosystems. Water is the primary medium through which the impact of climate change is going to be felt in South Africa.' ${ }^{78}$ The impact of climate change will also differ across the country - the arid interior (the Karoo region in particular) is expected to experience larger increases in temperature than the coastal regions. ${ }^{79}$ The IFs system includes in its integrated forecast a 1,9\% average decline in rainfall for South Africa up to 2030 and 2,1\% by 2035. (These are compared to 1990 levels.) This is not included in the water supply forecasts in this paper.

Johannesburg was founded on gold, with little thought given to the city's proximity to freshwater resources. It is one of the few major cities in the world built on a water divide. This means that South Africa's economic centre is in a very unfavourable location it terms of water supply. The Vaal River supplies most of the water for Johannesburg and some of Pretoria's. However, the Vaal flows through mining and powergeneration plants before reaching many municipalities where its water is used for human consumption. Acid mine drainage and other pollutants contaminate this water and there is little wastewater treatment in these industries. The current strategy to address contaminated drinking water is through dilution water is released from the Vaal Dam to dilute the water enough so that it is suitable for human consumption. This is obviously not a sustainable solution and 
a significant waste of clean water. ${ }^{80}$ While this paper does not explicitly model water quality, contaminated water presents a real threat to the South African water supply.

In fact, the legacy of pollution in the mining sector after more than a century of gold and other mineral extraction is such that the South African futures 2030 paper, referred to earlier, included the impact of acid mine water as a potential wild card for the country: 'Should polluted mine water accumulating from more than a century of gold mining reach the surface in the Witwatersrand Basin and flow into the Vaal River, it could pollute the entire downstream basin of the Orange River. This would have a major impact on farming and people's livelihood.' 81

\section{Conclusion}

South Africa is facing a potential water crisis and the current policies of the newly named Department of Water and Sanitation are not sufficient to address this problem. Although not impossible to achieve, the reductions in demand and increases in supply necessary to close the gap outlined in this paper, are very optimistic. Increases in water supply cannot match the expected increase in demand without additional and farreaching interventions. The water crisis cannot be solved through engineering alone - demand management in terms of both efficiency and allocation will have to play a large part in the efforts to close the water demand-supply gap in South Africa.

In line with some of the key messages from the reconciliation strategies laid out in the NWRS2, it is evident that 'South Africa cannot afford to waste any water, anywhere, any more'. ${ }^{82}$ More specifically:

- Groundwater is important, and currently undervalued and under-used, especially in small-scale rural farming.
It may emerge as the most important way in which any expansion in the agricultural sector is possible. The reality is that reallocating some water from irrigation to other use may have to be considered in certain areas.

- There is huge potential to increase the reuse of municipal and industrial water at the coast and in inland systems. In addition, wastewater needs to be treated in all water-use sectors, especially in highly contaminating industrial sectors, such as mining.

- There is limited opportunity for more dams or transfer schemes, but they are inevitable in certain areas. This option is very expensive.

- Due to the high levels of evaporation and transpiration loss in South Africa, the storage of water in aquifers has to be considered as part of future policy or alternative ways need to be found to reduce evaporation.

- Expensive desalination projects would have to be considered as an option to increase supply of water, especially in coastal areas with limited alternative sources of supply.

- The necessary incentives should be put in place for the transition to a recycling economy, in which water of different quality and price is used for different purposes.

- Monitoring and evaluation of the water sector is necessary to set and achieve the goals outlined in this paper.

Over-exploiting water threatens the health and prosperity of South Africa. While there is great uncertainty regarding the future of water demand and supply, it is clear from the forecasts presented here that a business-as-usual future scenario for water in South Africa will result in an unsustainable gap between supply and demand for many years. This gap represents a large risk - a risk that water may become a finite constraint to economic development and a crisis could ensue. This paper addressed this risk by quantifying the supply-demand gap and speculated on the consequences of an inability to close this gap. Although we refer to the issue of acid mine drainage, we do not discuss this issue at length, despite the threat that it poses on various fronts. ${ }^{83}$

South Africa has a diverse and active community engaged in water issues. Despite the sterling efforts by the Water Research Commission, the lack of publicly available and easily accessible data is a major problem in researching water supply and demand in South Africa. The excessive use of consultants and inability to capture and integrate the associated research results presents a serious constraint on planning and accountability. 


\section{Annex: Modelling water in International Futures (IFs)}

\section{The International Futures forecasting system}

International Futures (IFs) is large-scale, long-term, integrated modelling software housed at the Frederick S. Pardee Center for International Futures at the Josef Korbel School of International Studies at the University of Denver. The Pardee Center is in partnership with the Institute for Security Studies through the African Futures Project, and the partners have published a series of papers on various aspects relating to the implementation of South Africa's National Development Plan and African development. ${ }^{84}$ The International Futures model uses more than 2500 historical data series for 186 countries and sophisticated algorithms based on academic literature to create scenarios to the year 2100 .

The IFs system allows us to see past relationships between variables, and how they have developed and interacted over time. The International Futures base-case forecast represents where the world seems to be heading given our history and current circumstances and policies. The potential to undertake scenario analysis augments the base case by exploring the leverage that policymakers have to push the systems towards more desirable outcomes. The IFs software consists of 11 main modules: population, economics, energy, agriculture, infrastructure, health, education, sociopolitical, international political, technology and the environment. Each module is closely connected with the others, creating dynamic relationships among variables across the entire system. The full model is available at pardee.du.edu/ access-ifs.

This paper is the first publication that uses the new water sub-module of the IFs model, currently in development. This water segment forecasts water demand by sector and water supply by source for all 186 countries in the model and will be publicly available in IFs version 7.07 onward.

The forecasts used in this paper were done using International Futures version 7.0.

\section{Modelling water supply and demand in IFs}

This paper models total water supply using the IFs system as the sum of exploitable surface-water resources, exploitable groundwater resources, fossilwater withdrawal, desalinated water and directly reused treated wastewater.

Surface water can be found in lakes, rivers or streams and is a function of the mean annual run-off. Run-off is the portion of rainfall that does not infiltrate the surface or get otherwise intercepted; it therefore accumulates in rivers and streams. Run-off can also be fed by groundwater, which naturally feeds into streams and lakes.

Groundwater is water that infiltrates the surface and percolates downwards into aquifers. Groundwater can be recharged through precipitation, seepage from surface water, or by means of engineering solutions that recycle used water that has been rendered safe. ${ }^{85}$ Not all groundwater recharges at the same rate. Fossil water is groundwater that recharges at such a slow rate it can be thought of as a non-renewable resource. Recharge rates of zero are rare but many aquifers take hundreds or even thousands of years to recharge. ${ }^{86}$ These aquifers can be extremely large: excluding water held in glaciers, aquifers (both renewable and non-renewable) make up about $97 \%$ of the world's freshwater resources. ${ }^{87,88}$

Reused water represents another source of fresh water. Water can be reused either within or among sectors. For example, an industrial facility can reuse water for multiple purposes (i.e. within the sector) or it can reuse municipal wastewater (i.e. among sectors). Some of this wastewater is directly reused and some is released back into the water catchment, and made available for use as a so-called secondary water source.

Salt water, brackish water or otherwise contaminated water can be desalinated and converted into clean fresh water.

Figure 10: Water supply within International Futures

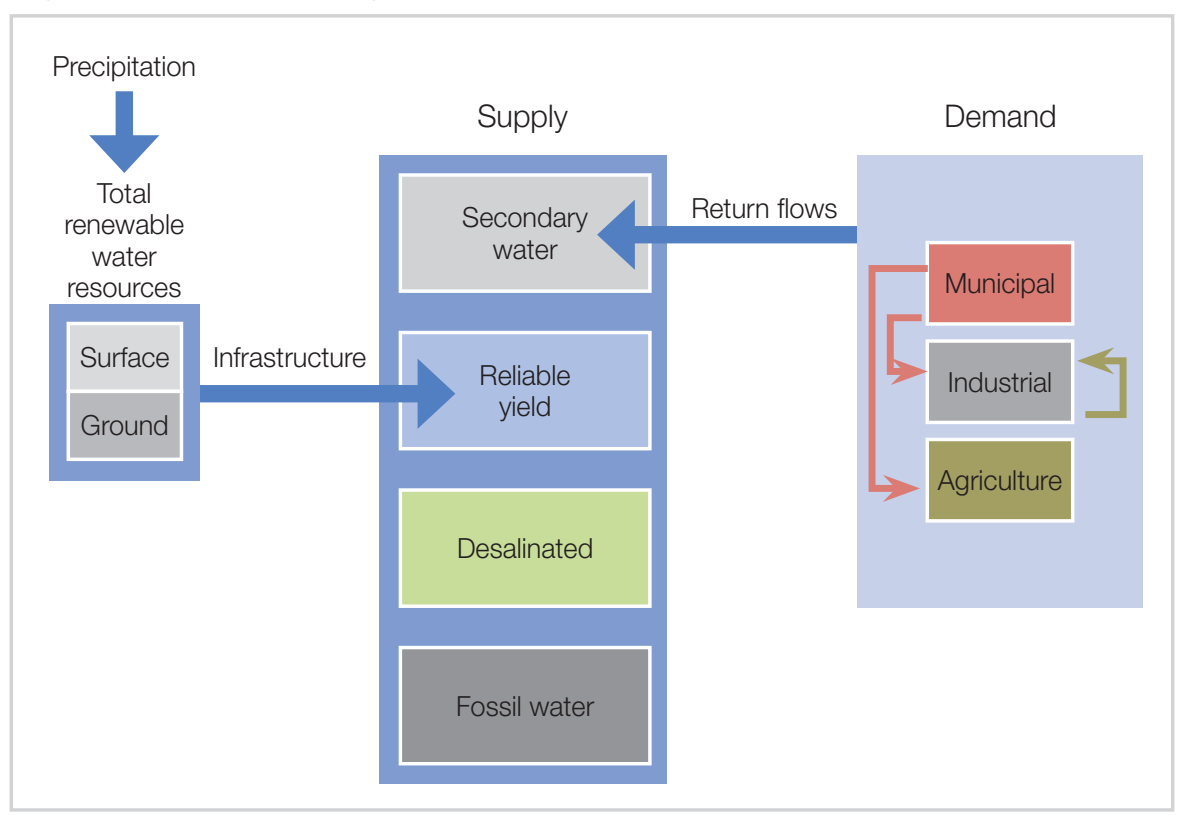

Source: Author's conceptualisation of the water segment of IFs. 
This process is energy-intensive and expensive but given the increasing scarcity of other water resources and improved desalination technology, the cost of desalination is becoming comparable to freshwater withdrawal.

Using IFs, the authors forecast the total amount of produced wastewater as a function of municipal water demand. They then used GDP per capita to forecast the portion of produced wastewater that is treated, since statistical analysis indicates a clear relationship between these two variables - the higher the GDP per capita the higher proportion of produced wastewater is treated.

\section{Figure 11: Water demand and return flows using the IFs model}

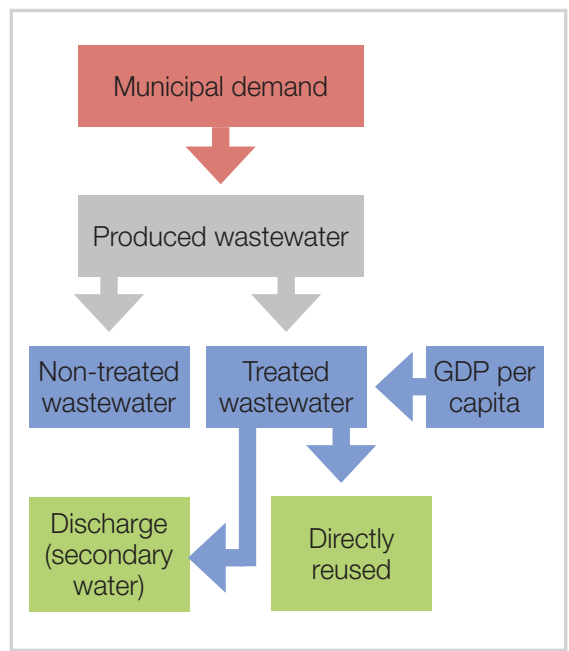

Source: Author's conceptualisation of the water segment of IFs.

\section{Base case}

The base case used in this paper has been adjusted slightly from the IFs base case. The authors have included the increased population forecast that appears in the 'Bafana Bafana' scenario from the paper South African futures 2030, and originally developed from the African Futures Paper by Go, Moyer, Rafa and Schünemann, Population futures: Revisiting South Africa's National Development Plan 2030. ${ }^{89}$

\begin{tabular}{|l|l|l|}
\hline \multicolumn{1}{|c|}{ Variable name } & \multicolumn{1}{|c|}{ Description } & \multicolumn{1}{c|}{ Value } \\
\hline migrater & $\begin{array}{l}\text { Migration rate (inward), } \\
\text { net percentage of } \\
\text { population }\end{array}$ & $\begin{array}{l}\text { 0,3 over entire time } \\
\text { horizon }\end{array}$ \\
\hline population & $\begin{array}{l}\text { Total population } \\
\text { (millions) }\end{array}$ & 50,9445 \\
\hline
\end{tabular}

\section{Close the gap scenario}

This scenario includes the interventions described above in the base case scenario as well as:

\begin{tabular}{|c|c|c|}
\hline Variable name & Description & Value \\
\hline wastewaterportiontreated & $\begin{array}{l}\text { Portion of produced } \\
\text { wastewater that is } \\
\text { treated }\end{array}$ & $\begin{array}{l}0,43 \text { in } 2010 \text { and } \\
\text { interpolated to } 0,8 \text { by } \\
2035\end{array}$ \\
\hline waterdesalinatedm & $\begin{array}{l}\text { Desalinated water } \\
\text { multiplier }\end{array}$ & $\begin{array}{l}1 \text { in } 2010 \text { and } \\
\text { interpolated to } 1,7 \text { by } \\
2035\end{array}$ \\
\hline waterefficiencym & $\begin{array}{l}\text { Water efficiency } \\
\text { multiplier (municipal) }\end{array}$ & $\begin{array}{l}1 \text { in } 2010 \text { and } \\
\text { interpolated to 1,25 by } \\
2035\end{array}$ \\
\hline waterefficiencym & $\begin{array}{l}\text { Water efficiency } \\
\text { multiplier (industrial) }\end{array}$ & $\begin{array}{l}1 \text { in } 2010 \text { and } \\
\text { interpolated to } 1,1 \text { by } \\
2035\end{array}$ \\
\hline waterefficiencym & $\begin{array}{l}\text { Water efficiency } \\
\text { multiplier (agriculture) }\end{array}$ & $\begin{array}{l}1 \text { in } 2010 \text { and } \\
\text { interpolated to 1,02 by } \\
2035\end{array}$ \\
\hline watersexploitrenewm & $\begin{array}{l}\text { Exploitable water } \\
\text { resources multiplier } \\
\text { (surface) }\end{array}$ & $\begin{array}{l}1 \text { in } 2010 \text { and } \\
\text { interpolated to } 1,1 \text { by } \\
2035\end{array}$ \\
\hline watersexploitrenewm & $\begin{array}{l}\text { Exploitable water } \\
\text { resources multiplier } \\
\text { (ground) }\end{array}$ & $\begin{array}{l}1 \text { in } 2010 \text { and } \\
\text { interpolated to } 1,25 \text { by } \\
2035\end{array}$ \\
\hline
\end{tabular}

\section{Notes}

1 World Economic Forum, Global Risks 2014 Ninth Edition. http://www3.weforum.org/ docs/WEF_GlobalRisks_Report_2014.pdf (accessed 15 April 2014).

2 National Planning Commission, National Development Plan 2030: Our future - make it work, 2012, 95

3 Statement made on 3 September 2013, on water policy and fracking in the Karoo. The 98\% allocation came from NWRS1 in 2000 , using data from 1998. Subsequently the total volume of water available was revised downward. For information on the overestimation of resources, see BJ
Middleton and AK Bailey, Water resources of South Africa, 2005 study (WR 2005), Water Research Commission Report No. TT 381/08, Pretoria: Water Research Commission, 2008, www.wrc.org.za/Knowledge\%20 Hub\%20Documents/Research\%20Reports/ TT-381\%20complete.pdf (accessed 30 April 2014).

4 Department of Water Affairs, National Water Resource Strategy 2013 (NWRS2), www. dwaf.gov.za/nwrs/NWRS2013.aspx, 9. (accessed 17 March 2014).

5 Singapore Red Cross, Pakistan floods: The deluge of disaster - facts and figures as of 15 September 2010, www.reliefweb.int/ report/pakistan/pakistan-floodsthe-deluge- 
disaster-facts-figures-15-september-2010 (accessed 14 June 2014); Salmon Masood and Kevin Drew, New flood warnings raise fears in Pakistan, The New York Times, www.nytimes. com/2010/08/13/world/asia/13pstan.html?_r=0 (accessed 14 June 2014)

6 Jonathan Kaiman, China says more than half of its groundwater is polluted, The Guardian, www. theguardian.com/environment/2014/apr/23/ china-half-groundwater-polluted?CMP=twt_gu (accessed 14 June 2014)

7 See, for example, F Winde, Uranium pollution of the Wonderfontein Spruit, 1997-2008. Part 1: Uranium toxicity, regional background and mining-related sources of pollution, Water SA, 36:3, 239-256; F Winde, Uranium pollution of the Wonderfontein Spruit, 1997-2008. Part 2: Uranium in water - concentrations, loads and associated risk, Water SA, 36:3, 257-278.

8 See, for example, Köln von Loga, et al, Reliance on existing wetlands for pollution control around the Witwatersrand gold/uranium mines in South Africa - are they sufficient? In BJ Merkel, B Planer-Friederich and C Wolkersdorfer (eds), Uranium in the aquatic environment, Berlin: Springer, 2002

9 See, for example, FG Bell et al, Environmental impacts associated with an abandoned mine in the Witbank coalfield, South Africa, International Journal of Coal Geology, 45, 2001, 195-216; JN Blignaut and NA King, The externality cost of coal combustion in South Africa, paper presented at the First Annual Conference of the Forum for Economics and the Environment, Cape Town, 2002; Management of environmental impacts from coal mining in the Upper Olifants River catchment as a function of age and scale, in MJ Patrick, J Rascher and AR Turton (eds), Reflections on water in South Africa, special edition of International Journal of Water Resource Development, 24:3, 417-432.

10 To deal with the matter of equity, the Department of Water and Sanitation has put in place a Water Allocation Reform programme, which includes 'water set aside specifically for redress, compulsory licensing, general authorisations, development support and partnerships to ensure that water is made available to previously disadvantaged groups.' NWRS2, iii.

11 Food and Agriculture Organization, Coping with water scarcity: An action framework for agriculture and food security, 2008, www. zaragoza.es/contenidos/medioambiente/onu// newsletter12/880_eng.pdf (accessed 12 June 2014).

12 Ibid. We use the same classifications as the $\mathrm{FAO}$.

13 Department of Water Affairs, National Water Resource Strategy, 2013, 8.

14 World Bank, World DataBank, 2013, http:// data.worldbank.org/indicator/AG.LND.PRCP. MM (accessed 20 March 2014).

15 National Oceanic and Atmospheric Administration. National Climatic Data Center.
Global Analysis - Annual 2013. http://ncdc. noaa.gov/sotc/global/2013/13 (accessed 3 September 2014)

16 Food and Agriculture Organization, Aquastat country profiles (South Africa), www.fao.org/nr/ water/aquastat/countries_regions/south_africa/ index.stm (accessed 16 August 2013).

17 National Planning Commission, National Development Plan 2030: Our future - make it work, 177.

18 Ibid., 179

19 Water Research Commission, McKenzie et al., The state of non-revenue water in South Africa, 2012, www.wrc.org.za/Knowledge\%20 Hub\%20Documents/Research\%20Reports/ TT\%20522-12.pdf, ix (accessed 15 June 2014).

20 President Jacob Zuma, State of the Nation Address, 2010, www.thepresidency.gov.za/ pebble.asp?relid=11 (accessed 20 June 2014).

21 Water Research Commission, McKenzie et al., The state of non-revenue water in South Africa, 2012, www.wrc.org.za/Knowledge\%20 Hub\%20Documents/Research\%20Reports/ Tा\%20522-12.pdf, ix (accessed 15 June 2014).

22 See the 2013 Annual report on water services in South Africa, www.wrc.org. za/Knowledge\%20Hub\%20Documents/ Special\%20(ad-hoc)\%20Publications/MBI final\%20SMALLER.pdf (accessed 17 March 2014).

23 Department of Water Affairs, National Water Resource Strategy, 2013, 8.

24 Republic of South Africa, National Water Act (Act 36 of 1998), www.dwaf.gov.za/ Documents/Legislature/nw_act/NWA.pdf (accessed 1 July 2014).

25 The Department of Water Affairs and Sanitation has restructured the water-management areas into nine from the previous 19.

26 Department of Water Affairs, National Water Resource Strategy 2004, chapter 1, 8, www. dwaf.gov.za/nwrs/LinkClick.aspx?fileticket=Yaj MovkCG0\%3d\&tabid=63\&mid=412 (accessed 17 June 2014).

27 Ibid.

28 This is required in the National Water Act (Act 36 of 1998).

29 For a detailed review of access to water and sanitation, see Human Rights Commission, Water and sanitation, life and dignity: Accountability to people who are poor, 2014, www.sahrc.org.za/home/index.php?ipkConte $\mathrm{ntID}=15$ \&ipkMenulD=19 (accessed 17 March 2014).

30 National Planning Commission, National Development Plan 2030: Our future - make it work, 219.

31 Ibid., 145, 147, 179

32 BJ Middleton and AK Bailey, Water resources of South Africa, 2005 study (WR 2005), Water Research Commission Report No. TT 381/08,
Pretoria: Water Research Commission, 2008, www.wrc.org.za/Knowledge\%20Hub\%20 Documents/Research\%20Reports/TT-381\%20 complete.pdf (accessed 17 March 2014).

33 Written communication from Anthony Turton, 23 June 2014.

34 Department of Water Affairs, National Water Resource Strategy, 2013, 8.

35 Written communication from Anthony Turton 23 June 2014

36 PJ Ashton, D Hardwick and CM Breen, Changes in water availability and demand within South Africa's shared river basins as determinants of regional social-ecological resilience, in MJ Burns and AVB Weaver (eds), Advancing sustainability science in South Africa, Stellenbosch: Stellenbosch University Press, 2008, 279-310; NWRS2, 8. According to Professor Turton, this is an unlikely, high estimation.

37 Department of Water Affairs, National Water Resource Strategy, 2013, Annexure D, 3. NWRS2 (page 25) says that up to $14 \%$ is reused. It defines water reuse as secondary water withdrawals, as well as direct use of treated wastewater. This really just means that $14 \%$ of water that is used has already been used, which says nothing about the quality of the water. We do not include non-treated wastewater in our supply forecasts; see also PJ Oberholster and PJ Ashton, State of the Nation report: An overview of the current status of water quality and eutrophication in South African rivers and reservoirs, Parliamentary Grant Deliverable, Pretoria: Council for Scientific and Industrial Research, 2008.

38 Department of Water Affairs, National Water Resource Strategy 2004

39 Excluding renewable-energy generation.

40 Department of Water Affairs, National Water Resource Strategy, 9

41 National Planning Commission, Nationa Development Plan 2030: Our future - make it work, 219; Department of Water Affairs, National Water Resource Strategy, 10. The IFs model does not differentiate between land used for crop farming (which it calculates at 15,88 million hectares) and land under irrigation, including the 1,6 million of the latter in the former.

42 National Planning Commission, Nationa Development Plan 2030: Our future - make it work, 62.

43 Department of Water Affairs, National Water Resource Strategy 2013, 10.

44 National Planning Commission, National Development Plan 2030: Our future - make it work, 219.

45 Department of Water Affairs, National Water Resource Strategy 2013, 10.

46 Bureau for Food and Agricultural Policy, Implications of the NWRS2 on irrigation agriculture, its economic contribution, and the long-run sustainability, www.bfap.co.za/ 
documents/research\%20reports/BFAPPULA\%20-\%20The\%20evaluation\%20of\%20 irrigated\%20agriculture\%20(08-05-2013).pdf, 4 (accessed 17 March 2014)

47 For a more detailed analysis of population futures, including inter-province migration, see Ara Go, Jonathan Moyer, Mickey Rafa and Julia Schuenemann, Population futures: Revisiting South Africa's National Development Plan 2030, African Futures paper no 7, October 2013, www.issafrica. org/futures/publications/papers/populationfutures-revisiting-south-africas-nationaldevelopment-plan-2030 (accessed 14 Jan 2014).

48 Water Resources Group 2030, Charting our water future, www.sabmiller.com/files/reports/ charting_our_water_future.pdf (accessed 13 June 2014).

49 McKinsey \& Company, Confronting South Africa's water challenge, www.mckinsey.com/ insights/sustainability/confronting_south africas_water_challenge (accessed 21 June 2014).

50 Department of Water Affairs, A strategic overview of the water sector of South Africa 2013, www.nepadwatercoe.org/wp-content/ uploads/Strategic-Overview-of-the-WaterSector-in-South-Africa-2013.pdf. (No time horizon for this forecast is provided.) (accessed 15 Jan 2014).

51 Department of Water Affairs, National Water Resource Strategy 2013, 8.

52 Leandi Kolver, Lesotho Highlands Water Project Phase 2 launched, Engineering News, www.engineeringnews.co.za/article/ lesotho-highlands-water-project-phase-2launched-2014-03-27 (accessed 10 June 2014); Project Information Memorandum, Lesotho Highlands Water Project Phase 2, http://invest-tripartite.org/wp-content/ uploads/2013/06/14-Lesotho-HighlandsWater-Project-Phase-2-PIM-19-05-2013.pdf (accessed 10 June 2014).

53 Department of Water Affairs, National Water Resource Strategy 2013, Chapter 4.

54 Sapa, Govt moots desalination plant for Durban, Engineering News, www. engineeringnews.co.za/article/govt-mootsdesalination-plant-for-durban-2013-07-03 (accessed 4 July 2014).

55 The Water Research Commission, The water wheel, 2013, www.wrp.co.za/ sites/default/files/event_attachments/ WaterWheel_2013_1_Jan.pdf (accessed 30 June 2014).

56 McKenzie et al., The state of non-revenue water in South Africa 2012, Water Research Commission, http://www.wrc.org.za/ Knowledge\%2OHub\%20Documents/ Research\%20Reports/TT\%20522-12.pdf, ix (accessed 15 June 2014)

57 Ibid.

58 ibid., iv.
59 Department of Water Affairs, National Water Resource Strategy 2013, iii.

60 National Planning Commission, National Development Plan 2030: Our future - make it work, 179.

61 International Federation of Red Cross, South Africa: Drought, www.ifrc.org/docs/appeals/ rpts04/ZA040130.pdf (accessed 30 June 2014).

62 Ibid.

63 Tshepiso Mokhema, South Africa's North West province is drought-stricken, Bloomberg, www.bloomberg.com/ news/2013-09-18/south-africa-s-north-westprovince-is-drought-stricken-.html (accessed 20 March 2014)

64 Ibid.

65 Jakkie Cilliers, South African Futures 2030: how Bafana Bafana made Mandela Magic, ISS paper no 254, February 2014, http:// www.issafrica.org/publications/papers/southafrican-futures-2030-how-bafana-bafanamade-mandela-magic (accessed 20 June 2014).

66 Department of Water Affairs, National Water Resource Strategy 2013, 5.

67 Solving the water crisis with AMR, Infrastructure News, 30 January 2014, www. infrastructurene.ws/2014/01/30/solving-thewater-crisis-with-amr/ (accessed 20 March 2014).

68 This would necessitate reducing municipal water demand to $5,66 \mathrm{~km}^{3}$ by 2035 , a demand reduction of $1,52 \mathrm{~km}^{3}$

69 Cross-sectional analysis in IFs - agricultural water demand vs land equipped for irrigation.

70 Bureau for Food and Agricultural Policy, Implications of the National Water Resource Strategy 2 on irrigation agriculture, its economic contribution and the long-run sustainability, 2013, 9, www.bfap.co.za/ documents/research\%20reports/BFAPPULA\%20-\%20The\%20evaluation\%20of\%20 irrigated\%20agriculture\%20(08-05-2013).pdf (accessed 24 June 2014).

71 bid., 7.

72 Statement made by Minister of Water and Environmental Affairs Edna Molewa at a media briefing, Pretoria, 3 September 2013. For background information on the policy challenges, see Gerhard Backeberg, Water Research Commission, Constitutional change and natural resource policy reform in South Africa: Conducive or obstructive to sustainable economic growth of agriculture, 1996 and Gerhard Backeberg, Water Research Commission, Allocation of water use rights in irrigated agriculture: Experience with designing institutions and facilitating market processes in South Africa, 2007.

73 Written communication from Anthony Turton, 23 June 2014.

74 Ibid.
75 Estimated at $0,087 \mathrm{~km}^{3}$ by 2035 .

76 "Lesotho Highlands Water Project, Lesotho," water-technology.net, available at http:// www.water-technology.net/projects/lesothohighlands/ (accessed on 19 June 2014)

77 Known as dual stream reticulation.

78 Department of Water Affairs, National Water Resource Strategy 2013, 75

79 Ibid.

80 Pioneering work is being done on the treatment of acid mine drainage as a strategic initiative to overcome this legacy constraint.

81 Jakkie Cilliers, "South African futures 2030: how Bafana Bafana made Mandela Magic".

82 Department of Water Affairs, National Water Resource Strategy 2013, 11

83 See, for example, CSIR, Acid Mine Drainage in South Africa, Briefing Note 2009/02, August 2009, Pretoria.

84 See www.issafrica.org/futures.

85 G Tredoux, EC Murray, \& LC Cavé, 2002. Infiltration basins and other recharge systems in southern Africa. In A. Tuinhof, \& J.P. Heederik, (Eds.) 2002. Management of aquifer recharge and subsurface storage: making better use of our largest reservoir. NNC-IAH Publication No. 4. Wageningen: Netherlands National Committee of the International Association of Hydrogeologists.; AR Turton, \& FS Botha, 2013. Anthropocenic Aquifer: New Thinking. In S Eslamien, (ed) Handbook for Engineering Hydrology (Volume 3): Environmental Hydrology and Water Management. London: Francis \& Taylor. Chapter 59.

86 UNESCO, Non-renewable groundwater report, http://portalsostenibilidad. upc.edu/archivos/fichas/informes/ aguassubterraneasnorenovables.guiagestion. pdf (accessed 25 June 2014).

87 Ibid. The nubian sandstone aquifer system in North Africa, for example, is estimated to contain $14460 \mathrm{~km}^{3}$ of fresh water. See M Alker, The nubian sandstone aquifer system, in W Scheumann and E HerrfahrdtPähle (eds), Conceptualizing cooperation for Africa's transboundary aquifer systems, Bonn: German Federal Ministry for Economic Cooperation and Development, 2008, 231-274. (To put that figure in perspective, the entire USA used $458 \mathrm{~km}^{3}$ of water in 2011.), http://data.worldbank.org/indicator/ ER.H2O.FWTL.K3.

88 AM MacDonald et al, Quantitative maps of groundwater resources in Africa, http:// iopscience.iop.org/1748-9326/7/2/024009/ pdf/1748-9326_7_2_024009.pdf (accessed 26 June 2014)

89 Ara Go et al, Population futures: Revisiting South Africa's National Development Plan, www.issafrica.org/futures/papers/populationfutures-revisiting-south-africas-nationaldevelopment-plan-2030 (accessed 27 June 2014). 


\section{About the authors}

Steve Hedden has been a consultant for the Institute for Security Studies since March 2014 and a research assistant at the Pardee Center for International Futures since December 2012. He is currently finishing his master's degree in international development at the Josef Korbel School of International Studies in Denver, Colorado.

Jakkie Cilliers is the executive director of the Institute for Security Studies. $\mathrm{He}$ is an extraordinary professor in the Centre of Human Rights and the Department of Political Sciences, Faculty of Humanities at the University of Pretoria. He also serves on the International Advisory Board of the Geneva Centre for Security Policy in Switzerland and as a member of the board of advisers of the Center on International Conflict Resolution, Columbia University, New York.

\section{About the African Futures Project}

The African Futures Project is a collaboration between the Institute for Security Studies (ISS) and the Frederick S. Pardee Center for International Futures at the Josef Korbel School of International Studies, University of Denver. The African Futures Project uses the International Futures (IFs) model to produce forward-looking, policy-relevant analysis based on exploration of possible trajectories for human development economic growth and socio-political change in Africa under varying policy environments over the next four decades.

\section{Acknowledgements}

\section{Hanns \\ Seidel \\ Foundation}

This paper was made possible with support from the Hanns Seidel Foundation. The Institute for Security Studies is grateful for support from the members of the institute's Partnership Forum: the governments of Australia, Canada, Denmark, Finland, Japan, Netherlands, Norway, Sweden and the US.
ISS Pretoria

Block C, Brooklyn Court, 361 Veale Street New Muckleneuk, Pretoria, South Africa Tel: +27 123469500 Fax: +27 124600998 pretoria@issafrica.org

\section{The Frederick} S. Pardee Center for International Futures

Josef Korbel School of International Studies University of Denver 2201 South Gaylord Street Denver, CO 80208-0500 Tel: 303-871-4320 pardee.center@du.edu

www.issafrica.org/futures http://pardee.du.edu

@AfricanFutures

www/facebook.com/ AfricaFuturesProject 